\title{
Haurren autonomia goiztiarraren garapena eta Haur Hezkuntza Graduko irakaslegaiak. Aldagai parte-hartzaileak
}

\author{
The development of early childhood autonomy and the teaching staff \\ in Early Childhood Education. Intervening variables
}

\author{
Elena Herrán Izagirre*, Nuria Galende Pérez, Gorka Etxebarria Elordui \\ Bilboko Hezkuntza Fakultatea UPV/EHU, Bilbo, Bizkaia
}

\begin{abstract}
LABURPENA: Ikerlan honen helburua Haur Hezkuntza Graduko ikasleriak haur-autonomia goiztiarrarekiko (0-3 urte) dituen sinesteak ezagutzea da. Horretarako, galdetegi bat sortu eta aplikatu da, hasieran sendotasunik gabeko emaitzekin, eta hori dela eta parte-hartzaileen erantzunak zentratzeari ekin zaio. Emaitzek autonomia horren garapenaren hauskortasuna konfirmatu dute. Ikasleen sineste gutxi batzuk informatuak badira ere, hau da, unibertsitate formakuntzaren ondoriozkoak, gehienak sinplistak dira, haurtzaroan bizi izandako guraso-estiloei loturik. Sineste horiek generoaren, gradurako sarbide-ikasketen eta gradua egiten ari diren zentroaren titulartasunaren arabera aztertzeko orduan, lehenengoak koherente agertzen dira lanbide eta ikasketa hauen izaera feminizatuarekin; Lanbide-Heziketako Haur Hezkuntzako goi mailako ziklotik datorren ikasleriak lanbidearen alderdi praktikoak teorikoak baino hobeto baloratzeko joera adierazten du eta unibertsitateko zentroaren titulartasunak ere desberdintasunak agertzen ditu hezkuntza estiloa publikoa edo pribatua izatearen arabera.
\end{abstract}

GAKO-HITZAK: sinesteak, haur-autonomia goiztiarra, Haur Hezkuntzako Gradua, generoa, jatorriko ikasketak, zentroaren titulartasuna.

ABSTRACT: The aim of this study is to know the beliefs and attitudes of early childhood teacher training students concerning the autonomy of babies and toddlers (0-3). For such purpose, a questionnaire has been created and implemented, with inconsistent results initially, leading to the centering of the answers given by the participants employing the average of each subject for each item as individual norm. The results confirm the fragility of the development of early autonomy, because while the effect of university training on some questions in the form of informed beliefs is evident, it is poor among many others that are rather simplistic associated with the familiar educational styles experienced in childhood. We have proceeded to analyze the differences in these beliefs according to the following variables: gender, studies of origin and ownership of the center in which these studies are taken. The results obtained show significant differences by gender coherent with the feminized character of the profession and of the studies. Likewise, students that come from the Higher Degree in Pre-School Education tend to value differentially the practical aspects of the profession more than the theoretical ones. The ownership of the university center, private or public, also throws differences regarding the educational style.

KEYWORDS: beliefs, early autonomy, degree in early childhood education, teacher training, filter, centered scores, gender, previous training.

* Harremanetan jartzeko / Corresponding author: Elena Herrán Izagirre. UPV/EHU. Bilakaeraren eta Hezkuntzaren Psikollogia. Bilboko Hezkuntza Fakultatea. Sarriena auzoa, zk. g. - Leioa. Bizkaia - elena.herran@ehu.eus - http://orcid.org/00000001-8700-6103

Nola aipatu / How to cite: Herrán Izagirre, Elena; Galende Pérez, Nuria; Etxebarria Elordui, Gorka. (2020). «Haurren autonomia goiztiarraren garapena eta Haur Hezkuntza Graduko irakaslegaiak. Aldagai parte-hartzaileak». Tantak, 32(1), 33-58. (https:// doi.org/10.1387/tantak.20770).

Jasotze-data: 2018/04/19; Onartze-data: 2019/12/13

ISSN 0214-9753 - elSSN 2444-3581 / (c) 2020 UPV/EHU

(c) (i) Obra hau Creative Commons Atribución 4.0 Internacional-en lizentziapean dago 
Elena Herrán Izagirre, Nuria Galende Pérez, Gorka Etxebarria Elordui

\section{SARRERA}

Autonomia goiztiarra (Falk, 2018a; Kamii, 1982) Haur Hezkuntzako $(\mathrm{HH})$ oinarrizko eremu bat da. Autonomia aurre-programatutako gaitasun bat da eta gizakumea bultzatzen du inguruko munduarekin - fisikoarekin zein sozialarekin - mailaz maila era aktiboagoan eta independenteagoan eragitera (Tomasello, 2007; Wallon, 1985); eta gainontzeko garapen eremuak baldintzatzen ditu. Helduaren eta umetxoaren arteko harremana ez bada afektuzko eta errespetuzkoa, erraz bilakatu daiteke heteronomia (Kamii, 1982). «Autonomía significa ser gobernado por uno mismo. Es lo opuesto de heteronomía, que significa ser gobernado por algún otro» (Kamii, 1982, 4. or.). Edo, beste era batera esanda, autonomia faltsuaren hiru tranpa handietako batean jausi daiteke: «el condicionamiento, una exigencia de precocidad, de la que puede desprenderse una actitud de indiferencia y de abandono y una actitud de laissez faire» (Falk, 2018a, 111. or.). Lehen haurtzaroan hazkuntzaren kalitatea da gakoa, autonomia goiztiarrari laguntzeak umetxoek eta ume txikiek autokontrolerako estrategiak garatzea dakarrelako (Tarullo, Obradovic eta Gunnar, 2009). Autonomia bera autokontrolak barne-hartzen dituen funtzio betearazle goiztiarren iragarlerik onena denez (Field, 2010; Poulton, Moffitt eta Silva, 2015), lehen haurtzaroko autokontrola (Moffitt et al., 2011) helduaroko arrakastarekin lotzen da (Field, 2010; Poulton et al., 2015). Adimena edo estatus ekonomikoa ez bezala, autokontrola bizi arrakastaren iragarlea da (Duckworth, 2011), eta, gainera, autokontrola esku-hartzearen bitartez erraz hobetu daiteke (Moffitt et al., 2011). Horren harira, autodeterminazioaren teoriak eskainitako ikerketak (Deci eta Ryan, 1980) egiaztatzen du autonomia sostengatzen duen hazkuntza umetxoengan emaitza positiboekin lotzen dela, arauen barneratzea kasu, eta hazkuntzaren kontrola, aldiz, kalterako izaten dela (Joussemet, Landry eta Koestner, 2008; Moreau eta Mageau, 2013).

HHn, autonomiari dagokionez, sinesmenen artean bereizketa egin daiteke. Alde batetik, tradizionalak edo heldu-zentrikoak - helduengan zentratzen diren sinesmenak - ikuspegi defizitarioa edo mugen pertzepzioak abiapuntutzat hartzen dutenak, eta, bestetik, lehen haurtzaroaren gaitasunetan eta ahalmenetan zentratzen, garatzen eta oinarritzen direnak (Davis eta Degotardi, 2015), aurrerakoiagoak edo ume-zentrikoak - umeengan zentratzen direnak - . Azken horiek garapen aldi zehatz bakoitzean dagoen ume bakoitzari onena eta onuragarriena izan daitekeena proposatzen diote (Tonyan, Mamikonian-Zarpas eta Chien, 2013). Azken sinesmen-mota hori zaintza positiboago batekin eta ingurune aberatsago eta umeentzat estimulagarriago den hornidura batekin erlazionatu izan da, Pikler-Lóczy hezkuntza, kasu (David eta Appell, 2010; González-Mena, 2004; Herrán, 2014; Herrán, Orejudo, Martínez de Morentín eta Ordeñana, 2014), beste aldagai-mota batzuen eragina - taldearen tamaina, kasu - alde batera utziz (Clarke-Stewart, Vandell, Burchinal, O’Brien eta McCartney, 2002). 
Badirudi sinesmen tradizionalenak direla autonomia goiztiarraren gaineko ikerketa zientifikoaren emaitza sendoek ezaguera orokorrean eta hezkuntza-praktikan eraginik ez izatearen arrazoia (Pikler, 2018).

Zehazki, etorkizuneko profesionalen formazioan funtsezko gai bat kontuan hartu beharko litzateke: intuiziozko iragazkia (Goodman, 1988), beraren arabera prozesatzen dituztelako hurrengo hezkuntza- eta irakaskuntza-esperientzia guztiak (Lortie, 2002). Iragazki hori norberaren sinesmenetatik edo irudikapen sozialetatik eraikitzen da eta horiek pentsamenduaren oinarrizko gidak direnez, formazio akademikoa iragaziko dute ikasketa erabat baldintzatuz. Izan ere, Akin-ek (2013) baieztatzen du HHko irakaslegaiek ideia berriak ebaluatzeko beren berezko sineste sendoak erabiltzen dituztela, eta haiekin talka egiten dituzten guztiak gutxiesten, teorikoak, egin ezinak edo okerrak direla argudiatuz. Sinesteen eta informazio berrien artean ezinbestekoa da nolabaiteko kongruentzia (Opfer eta Pedder, 2011; Opfer, Pedder, eta Lavicza, 2011). Bestela, edukien jabetzea oso mugatuta geratzen da (Goodman, 1988; Raths, 2001), hurrengo hezkuntza- eta irakaskuntza-esperientzien probetxua bezalaxe (Lortie, 2002).

Sineste horiek nahitaez unibertsitate aurreko garaietan jatorria eta errotze sakon eta sendoa dituzten heinean, beharrezkoa da gurasoen heziketaestiloetara jotzea, umearen autonomiaren bilakaeraren gaineko sinesteen garapenaren eredu argitzaile gisa. Gurasoen heziketa-estiloak garapen-helburuek eta sozializazio-estrategiek osatzen dituzte (Goodnow, 1985). Azken horiek gurasoen portaera-joera global, egonkor eta irekitzat ulertzen dira, eta eragin handia eta garapen-ondorioak dituzte haurtzaroan zein nerabezaroan. Gurasoen diziplinari, kontrolari, nagusitasunari, euskarriari eta abarri buruzko jokaerak dira (Baumrind, 1991; Erikson, 1963; Gadeyne, Ghesquière eta Onghena, 2004; Rollins eta Thomas, 1979). Alderdi horien konbinazioek gurasoen heziketa-estiloak deiturikoak osatzen dituzte: elkarrekiko-autoritarioa, zapaltzailea-autoritarioa, permisibo-barkabera eta permisibo-axolagabea (MacCoby eta Martin, 1983). Hoffman-ek (1970) eredu autoritarioa, maitasun-erretira, eta indukzioa gehitzen ditu, eta Kellerhalls-ek eta Montandon-ek (1997), berriz, familia-estilo kontraktualista, estatutarioa eta maternalista proposatzen dituzte. Haiek guztiek barne hartzen dituzte, intentsitate-maila desberdinean, elkarrekikotasuna eta inplikazio afektiboa edo bien falta; kontrol sendo edo lasaia; maitasun-kentzea edo haserrea; mehatxu edo zigorraren erabilera; inposatzea zein lasaikeria edo indukzioaren erabilera, eta, hortaz, kontrako norabideetan kokatzen dira, eredu bat edo bestea indartuz.

Oso konplexua da unibertsitateko prestakuntza akademikoak haur-autonomia goiztiarraren ezagueran duen eragina ezagutzea. Arrazoien artean, adierazgarria den bat HHko Graduko berezko curriculumean kontraesanak izatea izan daiteke. Horiekin lotuta, ondorengo zikloetako edukiak hezkuntza goiztiarrera sinplifikatuak erakartzeko joera dago (Loizou eta Recchia, 2018). Nolanahi ere, prestatzen ari den irakaslegaiak hezitzaile informa- 
tutako bere profila eraikitzen du HHko Graduko esperientzia hezigarriaren eragin eraldatzailearen arabera. Horiek - nola edo hala - HHko titulazioan sortu izan dira haur autonomiarekin lotutako hezkuntza-egoeren eta hezkuntza goiztiarra osatzen duten zeregin profesionalaren inguruko ikusmoldeak eta sinesmenak zalantzan jartzeko, birplanteatzeko eta aukera egokiago emateko. Beraz, ikerketa honen helburua unibertsitateko prestakuntzak haur-autonomia goiztiarraren garapenean duen eragina aztertzea da. Horretarako, HHko lehenengo zikloan (0-3 urte) kokatutako eta autonomiarekin lotutako sozializazio- eta hezkuntza-jarraibideak ebaluatzeko eskala bat eraiki da. Bertan, haur-autonomia goiztiarraren eta bere baldintzen gainean lortutako ezaguera erantzunetan islatze maila neurtu nahi da. Emaitzak sineste informatutako eta konplexuekin lotzea espero da, beraien familia-testuinguruetako sineste tradizionalagoekin edo sinplistagoekin egin beharrean. Ondoren, lagina osatzen duten kolektiboen iruditerien sinesteak aztertzen dira hiru aldagairen arabera: generoa, HHko Gradurako sarbide-ikasketak eta aipaturiko gradua egiten ari diren zentroaren titulartasuna. Zehazki, feminizatutako lanbidea izanik, generoarekin lotutako kontuen balioespenean desberdintasunak aurkitzea espero da. Lanbide-Heziketako Haur Hezkuntzako goi mailako ziklotik datorren ikasleriaren iragazkia agerian geratzea espero da ere, batxilergotik datozenak baino praktikoagoak baita. Azkenik, unibertsitate-zentroaren titulartasuna pribatu edo publikoa izatearen arabera ere espero da itemen balioespenek heziketa-estiloarekin lotutako desberdintasun esanguratsuak erakuts ditzaten.

\section{METODOLOGIA}

\subsection{Metodoa}

Ikerketaren xedea, lehenik eta behin, deskribatzailea eta esploratzailea da, aztertu nahi baitu irakaslegaien sinesteak landuak eta HHko Graduko edukiekin koherenteak, edo sinplistak eta defizitarioak diren. Bigarrenik, diferentziala ere bada, HHko Graduko ikasleen artean generoaren, jatorriko ikasketen eta zentroaren titulartasunaren arabera autonomiaren garapen goiztiarraren gaineko sinesteetan desberdintasunak aztertzeko helburua duelako. Hau da, formatzen ari den ikasleriaren sinesmenak eta jarrerak bereiztu nahi dira, ea elaboratuak eta HHko graduaren edukiekin koherenteak diren ala sinplistak eta eskasak mantentzen diren.

\subsection{Parte-hartzaileak}

165 parte-hartzaile dira, HH Graduko unibertsitate ikasleak, \% 86 emakumeak, 19 eta 66 urte bitartekoak. Laginaren \% 54k burututako ikaskete- 
Haurren autonomia goiztiarraren garapena eta Haur Hezkuntza Graduko...

tarako ohiko adina du, hau da, 19-20 urte; \% 33k 21-24 urte ditu eta gainerako \% 13k 24 urte baino gehiagoko adina du. Adina gradu-ikasketen sarbidearekin lotuta dago: Batxilergoa, Lanbide-Heziketa eta 25 urte gorakoentzako Unibertsitaterako Sarbidea. Datuak EAEko bi zentro desberdinetan jaso dira, bata titulartasun publikokoa eta pribatukoa bestea. Aipatzekoa da 165 parte-hartzaileetatik 41ek Lanbide-Heziketako Haur Hezkuntzako Goi Mailako Gradua dutela.

\subsection{Neurketa-tresnak}

Lehenengo zikloan (0-3 urte) kokatzen diren eta aztertuko diren autonomiarekin erlazionatutako sozializazio- eta hezkuntza-jarraibideak, CUIDANDO 0-2 galdetegitik berreskuratu dira (Herrán et al., 2014), eta irakaslegaientzat moldatu da. Hortaz, haurren autonomiarekin erlazionatutako zazpi dimentsio edo alderdi berdinak dagozkien itemekin identifikatzen dira: umearen kontzeptua (ad.: hezkuntza goiztiarra 0-3 urteko umearentzat osasuntsua da), hezitzailearen rola (ad.: umeen arteko gatazkak konpontzeko hezitzailearen esku-hartzea ezinbestekoa da), eguneroko jarduera (ad.: siesta orduan ume guztiek lo egin beharko lukete), jarduerari lotutako sentimenduak (ad.: nire besarkadak, musu eta laztanak umearen ongizaterako ezinbestekoak direla uste dut), umeekiko elkarrekintza (ad.: edozein aurrerakuntza dela eta, txikia bada ere, umeak zorionduko ditut), hezkuntza-bikotearekin harremana (ad.: gelan gurekin lan egiten duten hezitzaile edo laguntzailearengan konfiantza profesionala izatea garrantzitsua da), ebaluazioa, berrikuntza eta hobekuntza (ad.: egunero egindako behaketak nire kideekin konpartituko ditut).

Dimentsio horiek neurtzeko 35 item diseinatu dira guztira eta partehartzaileek, adostasun-mailaren arabera, 1etik 5era ebaluatu behar zituzten, ordu eta erdiko tarte batez. Item guztiek umetxo edo ume txikiarekin zuzeneko esku-hartzeari - abisatzea, edo kokatu dadila uztea - zein zeharkako esku-hartzeari - eguna planifikatzea, partekatzea, etab.- e egiten diote erreferentzia. Tresnaren eraikuntza prozesuan, 20 profesional adituren irizpidea kontuan hartu zen, itemen sortze eta aukeraketari eduki-baliotasuna eman baitzioten.

\section{EMAITZAK}

\subsection{Datu-analisia}

Lehenik eta behin, oinarrizko azterketa deskriptiboak egin ziren, eta hainbat itemetan $-07,17,19,26,31,33$ eta $34-$ normaltasunetik oso urruneko banaketek aurkezten zituzten asimetria eta kurtosi koefizienteak 
aurkitu ziren. Item horiek ondorengo analisietatik kanpo utzi ziren, koefizienteen estimazioan albo-eragin garrantzitsuak ekiditeko asmoz.

Lehenengo deskribapen- eta esplorazio-azterketek argi erakutsi zuten tresnak ez zituela proposatutako dimentsioak modu sendoan neurtzen. Emaitzak azaldu zitzaketen elementu desberdinak esploratu ziren, alboeragin garrantzitsuen - onespena (Morales, 2000) edo desiragarritasun soziala (Edwards, 1953) - balizko presentzia aintzakotzat hartuz.

Arazo hori ebatzi edo arintzeko prozedura bezala, erantzunen zentratzeari ekin zitzaion (Schwartz, 2003), banakako arau bezala item bakoitzean subjektu bakoitzaren batezbestekoa erabiliz. Horrela, ez da puntuaketa gordinekin lan egin, baizik eta subjektu bakoitzaren batezbestekoarekiko puntuaketa erlatiboekin. Beraz, itemean lortutako puntuaketak, balorazio absolutua islatu beharrean, subjektuen artean gehien edo gutxien baloratua izan den islatzen du.

Aurreko hainbat ikerketetan (Solís, 2015) itemaren orientazioak portaera diferentziala erakutsi duenez, bakoitza bere aldetik aztertzen da; alde batetik, positiboki orientatutako itemak edo autonomia goiztiarraren aldekoak eta, bestetik, negatiboki orientatutakoak edo heteronomia goiztiarren aldekoak. Lehenengo taldea 15 itemez osatuta dago, HHko Graduan landutako edukiei edo autonomia goiztiarrarekin lotutako sineste informatuekin lotutakoak, lehen haurtzaroaren gaineko ikerketaren emaitza direnak. Bigarren taldea, berriz, 13 itemez osatuta dago eta HHko Gradutik kanpoko eduki eta sinesteak barne hartzen ditu, hau da, ikasleriak dakartzan heteronomia goiztiarrari lotutako sineste sinplistak. Beraz, azterketa deskribatzailerako item bakoitzeko puntuaketa zentratuaren batezbestekoaren araberako taula deskribatzaileak sortu dira itemen orientazioaren arabera banatuta: taula batean, orientazio positiboa edo autonomiaren garapenaren aldeko itemak, eta, beste batean, orientazio negatiboa edo heteronomiaren garapenaren aldekoak.

Azterketa diferentzialerako, Bariantzaren Analisia erabili da eta taldeen artean estatistikoki esanguratsuak ziren desberdintasunak identifikatu dira. Efektuaren tamaina kalkulatzeko, eta koefizientea erabili da. Taulak —zeinek, espazio-arrazoiengatik soilik, estatistikoki esanguratsuak diren desberdintasunak aurkezten dituzten - efektuaren tamainaren arabera ordenatuta aurkezten dira, modu errazean, item bakoitzean agertzen diren desberdintasun handienak ikusi ahal izateko.

\subsection{Azterketa deskribatzailea}

Emaitzetan autonomia eta heteronomia goiztiarrean banakako batezbestekoaren inguruan zentratutako puntuaketak aurkezten dira, datuen naturaltasun zentratua hobeto islatze aldera. 
Haurren autonomia goiztiarraren garapena eta Haur Hezkuntza Graduko...

1. taula

Autonomia goiztiarraren aldeko itemetako puntuaketa zentratuak

\begin{tabular}{|c|c|c|c|}
\hline Itemak & $N$ & $\bar{X}$ & $D \cdot t$ \\
\hline $\begin{array}{l}\text { 35. Beharrezkoa da 0-3 urte zikloko helburuak bikote edo } \\
\text { lankide pedagogikoarekin negoziatu eta partekatzea*. }\end{array}$ & 165 & .83 & .57 \\
\hline $\begin{array}{l}\text { 28. Eskolako egunerokotasuna zaintza jardueren inguruan } \\
\text { (pixoihal aldaketa, higienea, elikadura...) antolatzea ga- } \\
\text { rrantzitsua da. }\end{array}$ & 165 & .78 & .71 \\
\hline $\begin{array}{l}\text { 13. Ume bati mukiak kendu baino lehen, egingo diodanaz } \\
\text { ohartaraziko dut. }\end{array}$ & 163 & .74 & .69 \\
\hline $\begin{array}{l}\text { 18. Gelako umeen guraso edota familiekin harreman sen- } \\
\text { doak ezartzea gustuko dut. }\end{array}$ & 165 & .64 & .72 \\
\hline $\begin{array}{l}\text { 32. Bi urteko gelako tutoreak, umeekiko harremanari be- } \\
\text { gira laguntzaileak bezala, pixoihalak aldatu behar ditu. }\end{array}$ & 163 & .51 & .82 \\
\hline $\begin{array}{l}\text { 29. Ume batek beste bati jostailu bat kentzen dionean, bere } \\
\text { kidea jolasten dagoen bitartean jostailurik ezin diola } \\
\text { kendu gogorarazi behar diogu. }\end{array}$ & 165 & .51 & .80 \\
\hline 21. 0-3 urte arteko zikloan nire lana burutzeko gai naiz. & 164 & .35 & .71 \\
\hline $\begin{array}{l}\text { 22. Egunero egindako behaketak nire lankideekin parteka- } \\
\text { tuko ditut. }\end{array}$ & 164 & .19 & .88 \\
\hline
\end{tabular}

06. Egokitzapen garaian nire esku dagoen guztia egingo $\begin{array}{lllll}\text { dut gurasoengandik banatzean umeek negarrik egin ez } & 165 & -.04 & 1.13\end{array}$ dezaten.

11. Atsegin izango nuke 0-3 urte arteko umeei pixoihala aldatzeko unea.

$165 \quad-.39 \quad 1.01$

24. Nire seme-alabak nire gradu-zikloko ikaskideen zaintzapean lasai utziko nituzke.

$165 \quad-.48 \quad 1.12$

20. Egunerokotasunean umeen ongietorri eta agurrak ongi maneiatzeko gai izango naizen jakiteak kezkatzen nau.

$164-.60 \quad 1.07$

04. Umeari pixoihalaren aldaketan nahi duen jarrera aukeratzen uzteak bere segurtasuna indartuko du.

$163-.67 \quad 1.15$

25. Profesional on bat izateko garrantzitsuagoa da zuhurra edo erreflexiboa izatea, iaioa (praktikoa) baino.

$\begin{array}{lll}165 & -.94 \quad .97\end{array}$

10. Jatorduetan umeei jan nahi duten janari neurria erabakitzen utziko nieke.

* Zeharkako item guztiak kurtsibaz doaz taula guztietan, irakurketa errazteko. 
1. taulan autonomia goiztiarraren aldeko hamabost itemak aurkezten dira. Horietako zortzik batezbesteko positiboa dute eta beste zazpiek, negatiboa; beraz, azken horiek autonomiatik urrunduko lirateke. Lehenengo zortzien artean - positiboenak - umetxo edo ume txikiarekiko profesionalaren esku-hartze zuzenarekin lotutako bi aurki ditzakegu -13 eta $29-$. Bietan umetxoari edo ume txikiari egingo diotena jakinarazten zaio. 13ak, bere gaineko berehalako jarduera zuzenari buruz (.74), gertatuko denarekiko kontziente izaten laguntzen diona; eta 29ak, jostailuaren kudeaketa edo hezitzailearen betebehar batekin lotutako arau bati buruzkoa (.51). 6 itemek zeharkako kontuei egiten diete erreferentzia: 35ak, bikote pedagogikoarekin koordinatzeari (.83); 28ak, zaintzak jardueraren erdigunean kokatzeari (.78); 18ak, gurasoekiko harremanari (.64); 32ak, hezitzaileak eta laguntzaileak aldaketetan batera lan egiteari $(.51) ; 21 \mathrm{ak}$, autoestimu profesionalari (.35); eta 22ak, lankideekin behaketak partekatzeari (.19), hain zuzen. 35 eta 22 itemak erlazionatuta daudela badirudi ere, deigarria da bien arteko batezbestekoetan -.83 eta .19, hurrenez hurren - aurkitutako desberdintasuna. Lehenengoak - helburuak partekatzea derrigorrezkoa izatea - item guztien artean batezbesteko altuena du eta bigarrenak - nire behaketak partekatzea-, berriz, aukerakoa edo, behintzat, hain garrantzitsua izango ez balitz bezala agertzen da.

Batezbesteko negatiboa erakusten duten autonomiaren aldeko zazpi itemen artean, haietako lau umetxo edo ume txikiarekiko esku-hartze zuzenarekin lotuta daude $-06,11,24$ eta $10-$. 06ak banaketa afektiboa leuntzeko helduaren ardura planteatuko luke; $11 \mathrm{k}$, pixoihal aldaketaz disfrutatzea; 24ak, ikaskideez fidatzea eta 10ak, ahorakinaren kantitatea umeak berak kudeatzea, azken hau batezbesteko negatibo bereziki handia azaltzen duelarik (-1.42). Lehenengoaren balorazioa, negatiboa izan arren, mediatik oso gertu dago eta, gurasoetatik aldentzeari lotutako sufrimenduari erreferentzia egiten dionez, kezkagarria da, profesional bezala urtero gelan aurkituko duten egoera bat izango delako. Bigarrenaren - pixoihalaren aldaketa - balorazioak gustura egiten ez duten zerbait dela adierazten du. Jarduera nagusi bat da egunerokotasunean eta, horregatik, nahitaez ohikoa hezkuntza goiztiarrean; beraz, emaitza hau ere kezkagarria da. Hirugarrenak - gelakideen balioespena - aurrekoa baino balio handiagoz agerian uzten badu ere, laugarrenak askoz ere handiagoa litzateke, alegia, ikasleren batek umetxoaren esku utziko balu janariaren kantitatearen erabakitzea, gehienek ez lukete egingo inolaz ere, janari kontuetako autonomia goiztiarra mugatuz. Beste hiru item -20, 04 eta 25- esku-hartzearekin zeharka erlazionatzen dira. 04ak jarduerarekin lotutako autonomiari erreferentzia egiten dion bitartean, bloke honetako beste bi itemek konfiantzaren gaia haztatzen dute - 24arekin batera (zuzena) - ; 20a, eguneroko ongietorri eta agurren norberaren kudeaketan; eta 25a, eskaintzen zaien formakuntzarekin lotuta. Haien balorazioek aditzera ematen dute kideekiko konfiantza falta handia dutela, eguneroko familia-eskola trantsizioetan kezka falta 
Haurren autonomia goiztiarraren garapena eta Haur Hezkuntza Graduko...

handiagoa eta Unibertsitateko formakuntzan eskaintzen zaien eta euren praktikaren gaineko balorazioan oinarritzen den kontrol kustodia handia.

2. taula

Heteronomia goiztiarraren aldeko itemetako puntuaketa zentratuak

\begin{tabular}{lrrr}
\hline \multicolumn{1}{c}{ Itemak } & $N$ & $\bar{X}$ & $D \cdot t$ \\
\hline $\begin{array}{l}\text { 16. Nire besarkada, muxu eta laztanak umearen ongizate- } \\
\text { rako ezinbestekoak direla uste dut. }\end{array}$ & 165 & .87 & .84 \\
\hline $\begin{array}{l}\text { 23. Praktika aldian adin tarte honetako haurren hezkuntzari } \\
\text { buruz gradu-ziklo guztian baino gehiago ikasten da. }\end{array}$ & 165 & .73 & .96 \\
\hline $\begin{array}{l}\text { 30. Egokitzapena txarra izan arren umeak hezitzailearekin } \\
\text { harreman afektibo osasuntsua eraiki dezake. }\end{array}$ & 165 & .51 & 1.10 \\
\hline $\begin{array}{l}\text { 12. Jatorduetan, umeak platerean jarritako guztia bukatuko } \\
\text { balu, zeharo lasai geratuko nintzateke. }\end{array}$ & 165 & .40 & .91 \\
\hline
\end{tabular}

14. Nire ustez, ume batek esfinterrak kontrolatzen ikas de$\begin{array}{llll}\text { zan, egunero ordu berean pixontzian jesartzea aproposa } & 165 & .13 & .96\end{array}$ da.

09. Ezinbestekoa da umeen arteko gatazkak konpontzeko hezitzailearen esku-hartzea.

03. Garrantzitsuagoa da umearen mugimendu askea jar$\begin{array}{lllll}\text { duera autonomoetan errespetatzea, zaintza uneetan } & 163 & 06 & 1.22\end{array}$ baino (pixoihal aldaketa, higienea, elikadura).

\begin{tabular}{llllll}
\hline 05. Eskolatze goiztiarra (0-3) umeen osasunerako ona da. & 164 & .05 & .98
\end{tabular}
27. Haurrek txarto jokatzen dutenean gure haserrea adierazi behar diegu.
$165 \quad-.18 \quad 1.05$

08. Umea bere kabuz jesartzeko prest egon baino lehen esertzen badute nik ikasgelan ez nuke jarriko.

$163 \quad-.16 \quad 1.24$

15. Siesta orduan ume guzti-guztiek lo egin beharko lukete. $\begin{array}{llll}165 & -.60 & 1.15\end{array}$

02. Ikasgelan kaosa ekiditeko arau zurrunak ezartzeak lasaituko ninduke.

$\begin{array}{lll}165 & -.90 & .99\end{array}$

01. Besoetako umea eskolatzen denetik ahalik eta hezitzaile kopuru handienarekin erlazionatzea oinarrizkoa da.

Heteronomiaren aldeko itemen zerrendan (2. taula) balorazio positiboa duten zortzi item eta balorazio negatiborekin bost item aurkezten dira; 
azken horiek autonomia goiztiarraren garapenerantz positiboki baloratuak izan direnak baino zuzenduago daude. Autonomiaren garapenari jarraitzeko, azken horietatik hasiko gara; hau da, behetik gorantz.

2. taulako gutxien baloratutako itemek $-01,02,15,08$ eta $27-$ profesionalaren esku-hartze zuzena dakarte umetxo edo ume txikiarekin. 01ak gain-sozializazio goiztiarra planteatzen du eta batezbesteko negatibo oso altua aurkezten du (-1.17). 02 itemak gelako txukuntasunari eta hori mantentzeko arauen kudeaketari egiten dio erreferentzia. Lortutako balorazio erlatiboa $-.90 \mathrm{da}$, eta horrek itemaren norabideari buelta emango lioke, hau da, irakaslegaiek ez lukete arau zorrotzik aplikatuko kaosaren aurrean. 15 itemak siesta orduan homogeneizazioa planteatzen du, batezbesteko negatibo nahiko altuarekin (-.60); 08a, familia giroan hartutako jarreran atzera egitea; eta $27 \mathrm{a}$, haserrea hezkuntza-teknika moduan erabiltzea, batezbesteko nahiko baxuekin $(-.16,-.18)$. Hau da, gain-sozializazioarekiko nahiko kontrakoak izango lirateke, loan autonomiarako joera oso altuarekin eta hezkuntza-neurri emozional negatiboak erabiltzeko nahikoa joerarekin, haur-jarreraren garapenean familia zuzentzeko joera izateaz gain.

Heteronomian positiboki baloratutako zortzi itemen artean, hiru zuzen $-16,12$ eta 14 - eta zeharkako bost $-05,03,09,30$ eta 23 - aurkitzen dira. 16ak batezbesteko erlatibo handiena du $-.87-$. Berriemaile beraren adierazpen emozional bizien funtsarekin du zerikusia, bere balioespen altua azal lezakeena. Item horretan bi kontu elkartzen dira: alde batetik, emozionalitatea, eta bestetik, norberarena izatea. Berea -ikaslearenaizateagatik umetxoa txundituta geratu beharko litzateke, dirudienez. 12 itemak hezitzailea jateko platerean zerbitzatutakoa amaitzearen aurrean ipintzen du. Batezbesteko altua lortu du (.40), beraz, gai sentibera dela ondoriozta daiteke. 14 itemak ohitura bitarteko esfinterren kontrolaren ikasketa ikertzen du. Horren batezbestekoa heteronomian baxua da, metodorik ohikoena ez dela aditzera ematen duena. Zeharkako itemen artean, 05a da puntuaziorik baxuena duena (.05). Eskolatze goiztiarraren ontasuna planteatzen du eta bere erantzun erlatiboa oso baxua da. 03 itemak mugimenduaren garrantzia-kalitatea dagokion jardueraren arabera - umearen jarduera autonomoa edo helduak eskainitako zaintza - bereizten ditu, eta batezbesteko oso baxuarekin egiten du. 09ak gatazketan helduaren partehartzea arakatzen du, eta bere balioa ere oso baxua da. 30 itemak egokitzapen desegoki baten ondorioak ikertzen ditu. Emaitzei erreparatuz (.51), badirudi magikoa den nolabaiteko erresilientzia goiztiarraren agerpen bat antzeman dela, zeinek erreferentziazko hezitzailearekin harreman osasuntsu baten faltaren ondorio negatiboak arinduko lituzkeen. Azken itemak, 23ak, formakuntza lehentasunak ikertzen ditu, non argi eta garbi praktika aldiak nahiago dituzten (.73) formakuntza teorikoaren aldean. Joera hori bat dator 1. taulan 25 itemak adierazitakoarekin, eta intentsitate oso altuarekin eragiten $\mathrm{du}$. 
Haurren autonomia goiztiarraren garapena eta Haur Hezkuntza Graduko...

\subsection{Azterketa diferentziala}

3. taulak generoaren arabera aurkitutako desberdintasun estatistikoki esanguratsuak aurkezten ditu autonomiaren garapenerantz bideratutako itemen kasuetan. Ondoren, 4.taulan, heteronomiarekin lotutakoak aurkeztuko dira.

3. taula

Autonomia goiztiarraren aldeko itemetako puntuaketa zentratuak generoaren arabera

\begin{tabular}{|c|c|c|c|c|c|c|}
\hline & \multicolumn{3}{|c|}{ Batezbestekoa } & \multirow{2}{*}{$\mathrm{F}$} & \multirow{2}{*}{ Sig. } & \multirow{2}{*}{$\mathrm{Eta}^{2}$} \\
\hline & Emakume & Gizon & Guztira & & & \\
\hline $\begin{array}{l}\text { 24. Nire seme-alabak nire } \\
\text { gradu-zikloko ikaskideen } \\
\text { zaintzapean lasai utziko } \\
\text { nituzke. }\end{array}$ & -.58 & .14 & -.48 & 8.297 & .005 & .050 \\
\hline $\begin{array}{l}\text { 06. Egokitzapen garaian nire } \\
\text { esku dagoen guztia egingo } \\
\text { dut gurasoengandik bana- } \\
\text { tzean umeek negarrik egin } \\
\text { ez dezaten. }\end{array}$ & .04 & -.59 & -.04 & 5.993 & .015 & .036 \\
\hline $\begin{array}{l}\text { 25. Profesional on bat izateko } \\
\text { garrantzitsuagoa da zuhu- } \\
\text { rra edo erreflexiboa izatea, } \\
\text { iaioa (praktikoa) baino. }\end{array}$ & -1.02 & -.50 & -.95 & 5.621 & .019 & .034 \\
\hline
\end{tabular}

Emakume $(n=139)$, gizon $(n=22)$. Guztira $(n=161)$.

Autonomiaren aldeko itemei dagokienez (3. taula), hirutan generoaren araberako desberdintasun estatistikoki esanguratsuak $(p<.05)$ aurkitu dira, bi zuzenak $-24,06$ - eta bat zeharkakoa $-25-.24$ itemean - norbere seme-alabak ikaskideekin uztea - emakumeek balioespen oso negatiboa egiten dute (-.58), gizonek ertaina egiten duten bitartean (.14). 06 itemaren balioespena - egokitzapen aldiarekiko kezka - ertaina da emakumeen kasuan (.04) eta negatiboa gizonen artean (-.59). Zeharkako itemean $-25-$, erreflexiboa izatea iaioa baino, bi taldeetan balioespena negatiboa da, baina bereziki emakumeen kasuan $(-1.02)$, gizonekin konparatuta (-.50). Emaitzek adierazten dute, beraz, generoaren araberako hainbat desberdintasun dagoela. Horrela, emakumeek beren ikaskideekiko mesfidantza argia adieraziko lukete, lanbide nabarmenki feminizatua izatearekin koherentea izan litekeena (Anliak eta Beyazkurk, 2008), millennial estiloarekin erlazionatuta egoteaz gain (Clark eta Byrnes, 2015), beren burua hainbat aspek- 
tutan batezbestekoaren gainetik ikusten dituztelako. Era berean, emakumeak egokitzapenean gutxi kezkatuko lirateke, baina gizonak baino nahiko gehiago, eta nahiago lukete praktikotasuna hausnarketa baino (Avgitidou, Pnevmatikos eta Likomitrou, 2013; Vartuli eta Rohs, 2009).

4. taula

Heteronomia goiztiarraren aldeko itemetako puntuaketa zentratuak generoaren arabera

\begin{tabular}{|c|c|c|c|c|c|c|}
\hline & \multicolumn{3}{|c|}{ Batezbestekoa } & \multirow{2}{*}{$\mathrm{F}$} & \multirow{2}{*}{ Sig. } & \multirow{2}{*}{$\mathrm{Eta}^{2}$} \\
\hline & Emakume & Gizon & Guztira & & & \\
\hline $\begin{array}{l}\text { 02. Ikasgelan kaosa ekiditeko } \\
\text { arau zurrunak ezartzeak } \\
\text { lasaituko ninduke. }\end{array}$ & -.97 & -.45 & -.90 & 5.139 & .025 & .031 \\
\hline $\begin{array}{l}\text { 12. Jatorduetan, umeak plate- } \\
\text { rean jarritako guztia buka- } \\
\text { tuko balu, zeharo lasai ge- } \\
\text { ratuko nintzateke. }\end{array}$ & .45 & .00 & .39 & 4.656 & .032 & .028 \\
\hline $\begin{array}{l}\text { 14. Nire ustez, ume batek es- } \\
\text { finterrak kontrolatzen ikas } \\
\text { dezan, egunero ordu be- } \\
\text { rean pixontzian jesartzea } \\
\text { aproposa da. }\end{array}$ & .20 & -.27 & .13 & 4.583 & .034 & .028 \\
\hline
\end{tabular}

Emakume (n=139), gizon (n=22). Guztira $(n=161)$.

Heteronomiaren aldeko itemen artean, generoaren aldagaiari dagokionez (4. taula), hiru item zuzen - 02, 12 eta 14- agertzen dira desberdintasun estatistikoki esanguratsuekin $(p<.05) .02$ itemaren balioespena - kaosa ekiditeko arau zurrunak - erabat negatiboa da emakumeen artean (-.97), gizonen artean nahiko negatiboa den bitartean (-.45). 12 itemean emakumezkoek positiboki baloratzen dute umeak platerean dagoen guztia bukatzea (.45) eta gizonezkoek, aldiz, erdibidekojarrera agertzen dute (.00). 14 itemean joera hori mantentzen da: emakumeek neurrizko jarrera positiboa dute umea egunero pixontzian ordu berean jartzearekiko, esfinterrak kontrolatzen ikas dezan (.20), eta gizonek, aldiz, gai honen aurrean neurrizko jarrera negatiboa dute (-.27). Hiru item hauen balioespenek arauarekin eta ohituren ikasketa autoritarioarekin zerikusia dute. Emakumeak gelako kaosarekin gizonak baino permisiboagoak izango lirateke, baina zurrunagoak zerbitzatutako guztia bukatzearekin edo esfinterren kontrola baldintzatzearekin. Generoarekin lotutako kontuak dira, jakina. Dena den, familia giroan normalean amak egiten dituen lanak direnez, ikerketa sakonagoa egin beharko litzateke, antzinako janari- 
Haurren autonomia goiztiarraren garapena eta Haur Hezkuntza Graduko...

maitasun (Hamburg, Finkenauer eta Schuengel, 2014) ideiarekin edo garbitasun goiztiarraren exigentziarekin (Falk eta Vincze, 2018) lotutako kontu atabiko femenino batez - ikasleria femeninoak gurasoen hezkuntza-estiloetatik ikasia - ari garen jakiteko.

Aurreko formakuntzarekin lotutako balizko desberdintasunei dagokienez (batxilergoa vs. lanbide-heziketa), 5. taulak autonomiaren aldeko itemetan aurkitutako desberdintasunak aurkezten ditu eta 6.ak, heteronomiaren aldekoetan aurkitutakoak.

5. taula

Autonomia goiztiarraren aldeko itemetako puntuaketa zentratuak aurreko formakuntzaren arabera

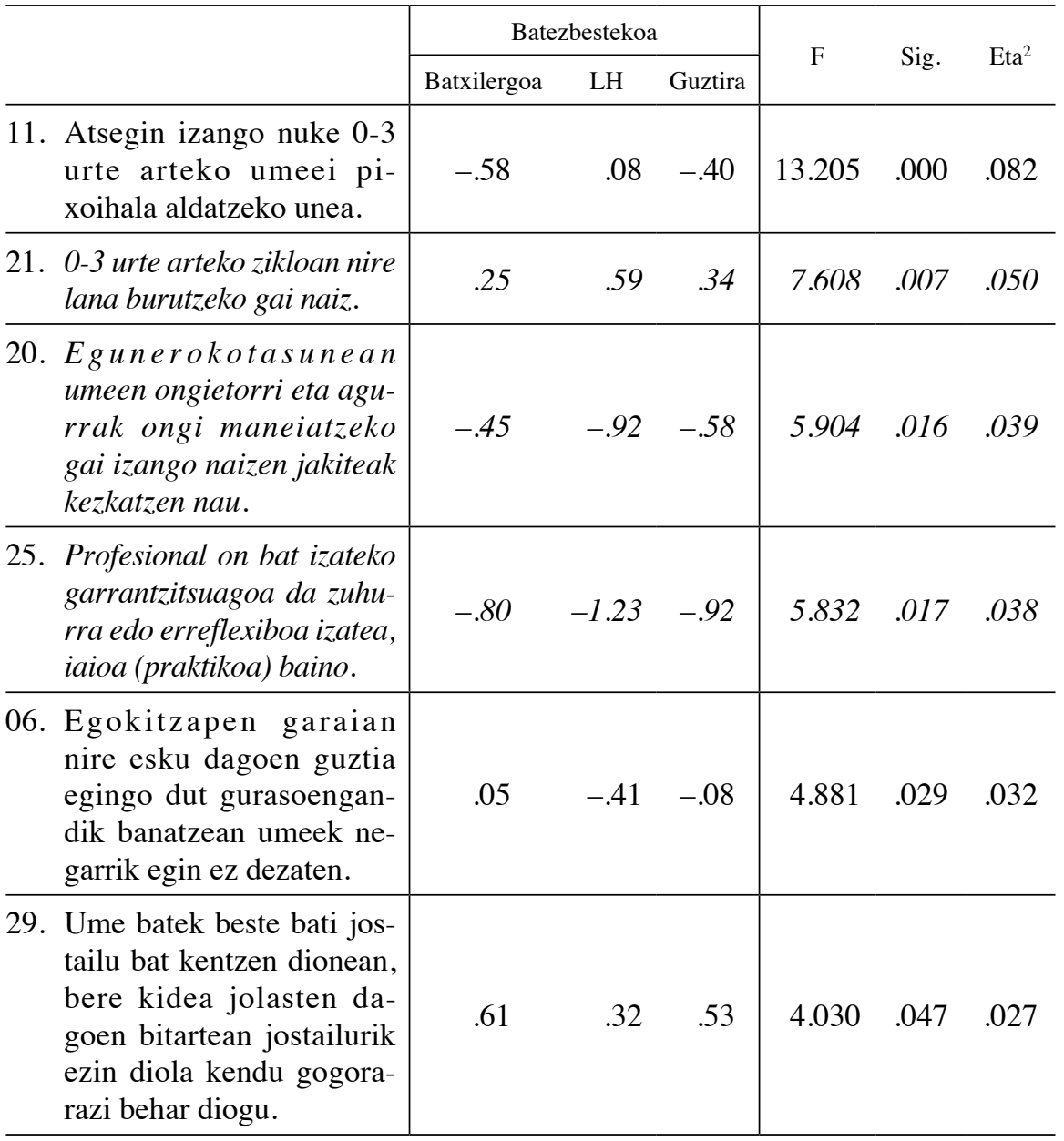

Batxilergoa $(n=108)$, LH $(n=41)$. Guztira $(n=149)$. 
Ikus daitekeenez (5. taula), sei itemek batxilergotik eta heziketaprofesionaletik eratorritako ikasleriaren arteko desberdintasun estatistikoki esanguratsuak $(\mathrm{p}<.05)$ aurkezten dituzte. Haietako hiru zuzenak dira $-11,06$ eta 29 - eta beste hiru, zeharkakoak $-21,20$ eta 25-. Lehenengoen artean, $11 \mathrm{n}$ - pixoihalaren aldaketa atsegin izatea - lanbide-heziketatik etorritako ikasleriak balioespen ertaina aurkezten du eta batxilergotik etorritakoak, balioespen negatibo argia (.08 eta -.58 , hurrenez hurren). Pixoihalaren aldaketari buruzko balioespenak bi taldeetan baxuak izan arren, haien arteko desberdintasunaren arrazoi posiblea da lanbide-heziketako eremu kurrikularreko edukia dela eta unibertsitate gradukoa, berriz, ez. 06 itemarekin - egokitzapen prozesuari buruzkoa - kontrakoa gertatzen da: batxilergoko ikasleek puntuaketa ertaina eskuratzen dute (.05), lanbide-heziketakoek balioespen negatibo argia ematen duten bitartean (-.41). 29 itemak jostailuen sozializazioari lotutako arauen kudeaketari egiten dio erreferentzia eta bi taldeetan balioespen positiboa jasotzen du, baina nabarmen altuagoa batxilergoko ikaslerian (.61), lanbide-heziketakoekin (.32) alderatuta. Zeharkako hiru itemetatik, 21 itemean, lana aurrera eramateko norbere gaitasunari buruzkoa, batxilergoko ikasleriak (.25) lanbide-heziketakoak (.59) baino balioespen baxuagoa egiten du, azken horiek 0-3 zikloan haien lana aurrera eramateko kapazago sentitzen direla baieztatuz. 20 itemaren balioespenak aditzera ematen du ez batzuk ez besteak ez direla eguneroko trantsizioengatik kezkatzen, baina lanbide-heziketako ikasleriak (-.92) batxilergokoak (-.45) baino kezka gutxiago azaltzen du. Azkenik, iaioa beharrean erreflexiboa izateari buruzko balioespena -25 itema- oso baxua da bi taldeetan, baina oraindik baxuagoa lanbide-heziketako ikaslerian (-1.23) batxilergokoan baino (-.80). Emaitza hauek bi taldeen arteko nolabaiteko haustura erakutsiko lukete. Beraz, lanbide-heziketako ikasleriak, batxilergotik datorrenarekin unibertsitate-formakuntza partekatu arren, intuiziozko iragazki bat aurkeztuko luke (Goodman, 1988). Iragazki horrek, batetik, egokitzapen aldiko edo jostailuen sozializazioan ematen diren zailtasunei erantzuteko erresistentzia, eta bestetik, pixoihal aldaketarekiko - gutxi bada ere - , euren jarduera burutzeko gai izatearen sentimenduarekiko, sarrera eta irteeren ardura murrizteko eta euren praktika hausnarketa baino gehiago baloratzeko joera indartzen ditu. Azken horiek HHko Graduko helburu formatzailea zalantzan jarriko lukete. Gainera, joera hori millennial estiloaren autosufizientziarekin lotu daiteke (Clark eta Byrnes, 2015), baita errealitate eta praktikaren arteko nahastearekin ere. Azken horiek sinonimotzat hartzen dira sinesmen sinplistetan, aurrerakoienek errealitatearen analisi eta gogoeta on bat, elementu teoriko nabarmenak aintzat hartuz, praktika benetan eraldatzailea gida dezakeen gauza bakarra dela partekatzen duten bitartean (Avgitidou et al., 2013; Vartuli eta Rohs, 2009). 
Haurren autonomia goiztiarraren garapena eta Haur Hezkuntza Graduko...

6. taula

Heteronomia goiztiarraren aldeko itemetako puntuaketa zentratuak aurreko formakuntzaren arabera

\begin{tabular}{|c|c|c|c|c|c|c|}
\hline & \multicolumn{3}{|c|}{ Batezbestekoa } & \multirow{2}{*}{$\mathrm{F}$} & \multirow{2}{*}{ Sig. } & \multirow{2}{*}{ Eta $^{2}$} \\
\hline & Batxilergoa & LH & Guztira & & & \\
\hline $\begin{array}{l}\text { 09. Ezinbestekoa da umeen ar- } \\
\text { teko gatazkak konpontzeko } \\
\text { hezitzailearen esku-har- } \\
\text { tzea. }\end{array}$ & .26 & -.29 & .11 & 9.340 & .003 & .060 \\
\hline $\begin{array}{l}\text { 23. Praktika aldian adin tarte } \\
\text { honetako haurren hez- } \\
\text { kuntzari buruz gradu-zi- } \\
\text { klo guztian baino gehiago } \\
\text { ikasten da. }\end{array}$ & .62 & 1.10 & .75 & 7.259 & .008 & .047 \\
\hline $\begin{array}{l}\text { 01. Besoetako umea eskolatzen } \\
\text { denetik ahalik eta hezitzaile } \\
\text { kopuru handienarekin erla- } \\
\text { zionatzea oinarrizkoa da. }\end{array}$ & -1.15 & -1.56 & -1.26 & 4.879 & .029 & .032 \\
\hline
\end{tabular}

Batxilergoa $(n=108)$, Lanbide Heziketa $(n=41)$. Guztira $(n=149)$.

6. taulan heteronomiaren aldeko itemak islatzen dira eta item horiek autonomiaren garapenaren aurkako portaerei egiten diete erreferentzia. Aurreko formakuntzaren aldagaiari dagokionez, desberdintasun estatistikoki esanguratsuak $(p<.05)$ topa daitezke item zuzen batean $-01-$ eta zeharkako bi itemetan - 09, 23-. 01 itemean - eskolatze goiztiarraren garaian umetxo eta ume txikiak ahalik eta hezitzaile kopuru handienarekin erlazionatzea - alderantzikatze bat gertatu da, bi taldetan balioespena negatiboa delako. Lanbide-heziketako ikasleen kasuan (-1.56) oso negatiboa da eta horrek itemaren norabidea aldatzen du, autonomoa bihurtuz. 09 itemean balioespena erdi-baxua da batxilergoko ikasleriarentzat (.26) eta dezente baxuagoa lanbide-heziketakoentzat (-.29). Hau da, batxilergotik datorren ikasleriarentzat hezitzaileak gatazketan esku hartzea egokia den bitartean, lanbide-heziketakoarentzat, ez, itemaren norabidea aldatuz, eta autonomiaren aldekoa bihurtuz. 23 itemak — practicumeko vs. Graduko ikasketabatxilergoko ikasleen artean balioespen ertain-altua (.62) aurkezten du, eta lanbide-heziketakoen artean, oso altua (1.10); horrek adierazten du bi taldeek practicumeko formakuntza Graduko bestelako formakuntza baino gehiago balioesten dutela, baina joera hori bereziki altua da lanbide-heziketatik datozenen artean. Emaitzek aditzera ematen dute lanbide-heziketatik datozen ikasleek bi itemen norabidea aldatzen dutela, autonomia- 
ren aldekoak bihurtuz: batxilergokoek baino dezente argiago dute gatazka goiztiar gehienetan helduaren esku-hartzea ez dela beharrezkoa (Tardos eta Vasseur-Paumelle, 2018). Era berean, badakite gizataldeetan ematen den hezkuntzan gertatzen diren lotura-harremanek pertsona heldu gutxirekin izan behar dituztela (Falk, 2013, 2018b). Berriro ere, praktikotasuna nagusitzen da gogoetaren gainetik, baina modu desberdinean; izan ere, lanbide-heziketako ikasleriaren balioespena askoz ere altuagoa da (Avgitidou et al., 2013; Vartuli eta Rohs, 2009).

Jarraian, 7. eta 8. taulek zentroaren titulartasunaren araberako desberdintasunak aurkezten dituzte, autonomiaren edo heteronomiaren garapenari dagokienez, hurrenez hurren.

7. taula

\section{Autonomia goiztiarraren aldeko itemetako puntuaketa zentratuak zentroaren titulartasunaren arabera}

\begin{tabular}{|c|c|c|c|c|c|c|}
\hline & \multicolumn{3}{|c|}{ Batezbestekoa } & \multirow[b]{2}{*}{$F$} & \multirow[b]{2}{*}{ Sig. } & \multirow[b]{2}{*}{$\mathrm{Eta}^{2}$} \\
\hline & $\begin{array}{c}1 . \\
\text { Zentroa }\end{array}$ & $\begin{array}{c}2 . \\
\text { Zentroa }\end{array}$ & Guztira & & & \\
\hline $\begin{array}{l}\text { 29. Ume batek beste bati jostailu } \\
\text { bat kentzen dionean, bere ki- } \\
\text { dea jolasten dagoen bitartean } \\
\text { jostailurik ezin diola kendu } \\
\text { gogorarazi behar diogu. }\end{array}$ & .20 & .69 & .51 & 14.700 & .000 & .083 \\
\hline $\begin{array}{l}\text { 10. Jatorduetan umeei jan nahi } \\
\text { duten janari neurria erabaki- } \\
\text { tzen utziko nieke. }\end{array}$ & -1.06 & -1.61 & -1.41 & 9.489 & .002 & .055 \\
\hline $\begin{array}{l}\text { 11. Atsegin izango nuke } 0-3 \text { urte } \\
\text { arteko umeei pixoihala alda- } \\
\text { tzeko unea. }\end{array}$ & -.08 & -.57 & -.39 & 9.175 & .003 & .053 \\
\hline $\begin{array}{l}\text { 06. Egokitzapen garaian nire } \\
\text { esku dagoen guztia egingo } \\
\text { dut gurasoengandik bana- } \\
\text { tzean umeek negarrik egin } \\
\text { ez dezaten. }\end{array}$ & -.35 & .14 & -.37 & 7.480 & .007 & .044 \\
\hline $\begin{array}{l}\text { 28. Eskolako egunerokotasuna } \\
\text { zaintza jardueren inguruan } \\
\text { (pixoihal aldaketa, higienea, } \\
\text { elikadura...) antolatzea ga- } \\
\text { rrantzitsua da. }\end{array}$ & .61 & .88 & .78 & 5.349 & .022 & .032 \\
\hline
\end{tabular}

1. Zentroa $(n=59)$. 2. Zentroa $(n=106)$. Guztira $(n=165)$. 
Haurren autonomia goiztiarraren garapena eta Haur Hezkuntza Graduko...

Zentroaren titulartasunaren aldagaiaren araberako autonomia goiztiarraren garapenaren aldeko itemetatik (7. taula), bostek desberdintasun estatistikoki esanguratsuak $(p<.05)$ aurkezten dituzte. Haietako lau autonomiarekin modu zuzenean erlazionatzen dira, eta bosgarrena, aldiz, zeharka. Azterketa deskribatzaileetan, haietako bat balioespen altuetan gelditu da (28), hiru balioespen ertainetan -29, 11 eta 06 - eta azken bat (10), balioespen oso baxuetan. 29 itemak balioespen ertain eta ertainaltuak aurkezten ditu. Item horrek sozializazioarekin lotutako arauen kudeaketari egiten dio erreferentzia. Esanguratasunari dagokionez, lehenengo itemean (29), 1. zentroa ez da 2. zentroa bezain aldekoa. Hau da, 1. zentroa 2.a baino permisiboagoa izango litzateke sozializazioaren kudeaketan eta horrekin lotutako mugen ezarpenean hezitzailearen partehartzeari dagokionez. 10 itema haur-autonomiarekin zuzenean erlazionatzen da; konkretuki, gosearen eta asetasunaren haur-autokontrolean konfiantza izatearekin. Item horrek aurkezten dituen balioespenak oso negatiboak dira, baina 1. zentroak hobeto puntuatzen du. Horrela, gosea autoerregulatzeko umearen gaitasunean 2. zentroak baino gehiago sinisten duenez, haur-autonomia gehiago sustatuko luke. 11 itemak balioespen ertain eta baxuak aurkezten ditu. Umetxo edo ume txikiari pixoihala aldatzeak eskaintzen duen harreman-gogobetetzeari eta gogobetetze instrumentalari egiten dio erreferentzia. Zentzu horretan, 1. zentroa da hobekien puntuatzen duena. Beharbada arrazoi sakona ez da 1. zentroko ikasleria ez dela gozatzekoaren aldekoa, baizik eta 2. zentrokoa kontrolatzaileagoa, ordenatuagoa eta zorrotzagoa dela, eta jarduera hori derrigortasunetik egiteko joera duela, lotutako plazerarekin baino. 06 itemak balioespen ertainak aurkezten ditu. Banatzearen sufrimendua leuntzeko enpatiaren gaia planteatzen du. 1. zentroak 2.ak baino emaitza baxuagoak lortzen ditu. Ongizatearen sustatzea autonomiaren baldintza da eta, beraz, 1. zentroa heteronomiara gehiago hurbilduko litzateke. 28 itemak balio altuak aurkezten ditu. Hezkuntza goiztiarraren muina zaintzak direla planteatzen du. Egunerokotasuna umetxo eta ume txikien beharrizanen eta haien erantzun eta gogobetetzearen inguruan eman behar dela kontutan hartzen du. Item horretan, 1. zentroaren balioespena 2.arena baino apur bat baxuagoa da. 
8. taula

Heteronomia goiztiarraren aldeko itemetako puntuaketa zentratuak zentroaren titulartasunaren arabera

\begin{tabular}{|c|c|c|c|c|c|c|}
\hline & \multicolumn{3}{|c|}{ Batezbestekoa } & \multirow[b]{2}{*}{$\mathrm{F}$} & \multirow[b]{2}{*}{ Sig. } & \multirow[b]{2}{*}{$\mathrm{Eta}^{2}$} \\
\hline & $\begin{array}{c}1 . \\
\text { Zentroa }\end{array}$ & $\begin{array}{c}2 . \\
\text { Zentroa }\end{array}$ & Guztira & & & \\
\hline $\begin{array}{l}\text { 09. Ezinbestekoa da umeen ar- } \\
\text { teko gatazkak konpontzeko } \\
\text { hezitzailearen esku-hartzea. }\end{array}$ & -.38 & .34 & .08 & 21.926 & .000 & .119 \\
\hline $\begin{array}{l}\text { 08. Umea bere kabuz jesartzeko } \\
\text { prest egon baino lehen eser- } \\
\text { tzen badute nik ikasgelan ez } \\
\text { nuke jarriko. }\end{array}$ & .15 & -.34 & -.16 & 6.031 & .015 & .036 \\
\hline $\begin{array}{l}\text { 12. Jatorduetan, umeak plate- } \\
\text { rrean jarritako guztia buka- } \\
\text { tuko balu, zeharo lasai gera- } \\
\text { tuko nintzateke. }\end{array}$ & .20 & .51 & .40 & 4.549 & .034 & .027 \\
\hline $\begin{array}{l}\text { 15. Siesta orduan ume guzti- } \\
\text { guztiek lo egin beharko lu- } \\
\text { kete. }\end{array}$ & -.85 & -.46 & -.60 & 4.495 & .036 & .027 \\
\hline $\begin{array}{l}\text { 30. Egokitzapena txarra izan } \\
\text { arren umeak hezitzaileare- } \\
\text { kin harreman afektibo osa- } \\
\text { suntsua eraiki dezake. }\end{array}$ & .74 & .39 & .51 & 3.984 & .048 & .024 \\
\hline
\end{tabular}

1. Zentroa $(n=59) ; 2$. Zentroa $(n=106)$. Guztira $(n=165)$.

Zentroaren titulartasunaren aldagaiaren araberako heteronomia goiztiarraren garapenaren aldeko itemetatik (8. taula), bostek zentroen arteko desberdintasun estatistikoki esanguratsuak $(p<.05)$ aurkezten dituzte eta heteronomiarekin zeharka erlazionatzen dira. Azterketa deskribatzaileetan, haietako batek balioespen ertain-altua lortu du (30), hiruk balioespen ertaina $-08,09$ eta $12-$ eta batek $-15-$, baxua. Erresilientzia goiztiarraren gaia planteatzen duen 30 itemak balio altuak aurkezten ditu. Emaitzen arabera, 1. zentroa 2.a baino aldekoagoa da: umeak, egokitzapena txarra izan arren, modu osasuntsuan eraiki dezake lotura afektiboa bere hezitzailearekin. Horrela, haur-erresilientziak hezitzailea egokitzapen osasuntsuari lotutako arduratik salbuetsiko luke. Sineste sinplista hori izatea norberarentzat oso lasaigarria da - emaitza modura, kezkagarri oso-, eta seguraski Weinstein-ek (1989) unrealistic optimism deiturikoari lotuta dago, hau da, 
Haurren autonomia goiztiarraren garapena eta Haur Hezkuntza Graduko...

egoera ideal eta ez errealei lotutako optimismoa, errealitate gogor eta ezezaguna alde batera utziz. Loaren autorregulazioari dagokiola (15 itema), balioespenak oso baxuak dira. 1. zentroak 2.ak baino baxuago puntuatzen du, beraz, permisiboagoa eta ez hain kontrolatzailea izango litzateke. 12 itemak balioespen ertainak aurkezten ditu, baina 2. zentroan apur bat altuagoak. Item horrek (12) gai atabiko bat aurkezten du, janari-maitasuna, hain zuzen, agian kontrolarekin lotuta; izan ere, aurreko itemean bezala (15), 1. zentroak baxuago puntuatzen du. 08 itemak ere balioespen ertainak aurkezten ditu. Umearen jarrera-kontrolari egiten dio erreferentzia (08). Gaiaren muinak zerikusia eduki dezake jarrera-kontrol autonomo eta indibidualaren meneratzearen kontzeptuarekin. Azken hau, ez garapen-tauletan ikasten dena, baizik eta ume bakoitzak aurkezten duenaren araberakoa. 09 itemak balioespen ertainak aurkezten ditu. Eguneroko gatazken aurrean haur-autonomiari erreferentzia egiten dio. Berriro ere, kontzeptuaren arabera, helduaren nagusitasunarekin edo haur-autonomiarekin lotu daiteke (09). Izan ere, sozializazioarekin lotutako gatazka txiki hauek gaizki ulertuak izaten dira, bullying-aren aitzindari bezala, inondik inora horrelakorik ez direnean (Tardos eta Vasseur-Paumelle, 2018).

\section{EZTABAIDA ETA ONDORIOAK}

Ikerketa esploratzaile honen emaitzek heuristiko indartsu bat osatzen dute, 0-3 zikloko hezitzaileen formakuntzako zailtasunen ulermenerako bide berriak eskainiz. Hurbiltze lan honek autonomiaren garapenaren hauskortasuna (Falk, 2018a; Kamii, 1982) eta autokontrolaren sustapena (Moffitt et al., 2011) hein batean konprometituta geldituko liratekeela baieztatuko luke. Gainera, erakutsiko lituzke aurretiko sinesmenen osagaiak eta haien prebalentzia unibertsitate formakuntzan, unibertsitatearen eragina proposatutakoa baino mugatuago delako. Eragin horrek badu zerikusia, batetik, graduaren beraren kontraesanekin eta, bestetik, geroagoko zikloetako edukiak adin goiztiarrari erakartzeko joerarekin (Loizou eta Recchia, 2018). Azken arrazoiei gizarte autoritario bateko gurasoen hezkuntza-estiloek HH Graduko ikasleen jarreretan, portaera intentzioetan eta sinesteetan irauten dutela gehitu beharko litzaieke.

Balioespenek sineste informatuen existentzia baieztatzen badute ere - esate baterako, egunerokotasunaren erdigunea zaintzak izatea, eta ez ipuinak kontatzea, abestea eta antzeko jarduera pedagogikoak; umeari jarraian gertatuko dena jakinaraztea; familiekin harremana izatea; edota umea erlazionatzen den hezitzaile kopurua murriztua izatea, David eta Appell (2010) eta Gerhardt-ek (2014) proposatzen dutenaren lerroan-, beste sineste sinplista batzuek ere badiraute (Brownlee, Berthelsen, Irving, Boulton-Lewis eta McCrindle, 2000) beraiekin batera eta oso indartsu. Horiek horrela, haserrea maitasun-erretira modalitate bat izango litzateke (Hoff- 
man, 1970). Betebeharra inposatzen da profesional desberdinen arteko koordinazioan edo zeregin beraren aurrean, baina ez hausnarketa pertsonalak partekatzeko uneetan. Zentzu berean, kontrola gailentzen da pixoihal aldaketan umeari nahi duen postura hartzen uzten ez zaionean, umeari ordu berean pixontzian esertzean edo janari-kantitatea erabakitzen uzten ez zaionean edota zerbitzatutako guztia bukatzera behartzen zaionean. Aurreko guztiak sozializazio goiztiarrean ematen diren botere eta kontrol autoritarioko estrategien adibideak izango lirateke (Rollins eta Thomas, 1979) eta haur-garapenean kalterako ondorioekin lotuko lirateke (Joussemet et al., 2008; Moreau eta Mageau, 2013).

Ume txikiek siestarik ez egitea edo ordena mantentzeko arau zorrotzak ez ezartzea autonomiaren aldeko siniste informatuaren adibidetzat jo daitezke, baina baieztatu beharko litzateke horrela den edo laissez faire jarrerara hurbiltzen diren. Aurreko guztiari magiazko erresilientzia gehitu beharko litzaioke, egokitzapena txarra izanda ere lotura osasuntsua hainbat egoeratan posiblea izango litzatekeelako, Masten-en (2001) ustearen zentzutik, baina beti ere porrotarekin lotutako arduratik salbuetsiz. Deigarria da ere eguneroko trantsizioen gaineko kezkarik ez agertzea, horiek ezinbestekoak izango balira bezala, kalte arinak baino ez. Jarrera horretan sakonduz, kontrolaren lagatzean zailtasuna topatuko genuke, Clark eta Byrnes-en (2015) millennial kontzeptuarekin erlaziona daitekeena. Funtsean harreman estua dauka autoestimu profesional altuarekin, formazio kideekiko nagusitasunarekin eta mesfidantzarekin - norbera baino gaizkiago formatuak egongo liratekelako-, etorkizuneko ikasleen gurasoei mesfidantzarekin - behar bezalako guraso izaten ez luketelako jakingo- eta ezezaguna eta inoren formazio teorikoarekiko mesprezua edo gutxiespenarekin - eskarmentu praktikoa erabat mugatua badute ere, propioa da- .

Deigarria da hezkuntza goiztiarrean funtsezkoak diren beste gai batzuk positiboagotzat ez hartzea; esate baterako, haur-osasunerako onurak, gatazkak, mugimendu autonomoa sustatzea, egokitzapen egokian inplikatzea, pixoihalaren aldaketa harreman pribilegiaturako momentu bezala disfrutatzea edo kideekin hausnarketak partekatzea. Inplikazio falta, laissez faire jarrerarekin lotu badaiteke ere, kontu hauei buruzko ezagutza faltaren ondorioa izan zitekeen. Nahierarako azalpen emozionalak - musuak, besarkadak, laztanak - estilo maternalistarekin (Kellerhalls eta Montandon, 1997) lotutako oso sineste herrikoiak eta zabalduak dira, familia zabala eta hezkuntza kooperatiboa (Hrdy, 2009) zeneko funtzionamendutik hurbil. Portaera horrek egungo haur-hezkuntza -instituzionala eta kolektiboaeta familia-hezkuntza - intimoa eta bakarrekoa - nahastuko lituzke, nahiz eta bietan lotura afektiboa eta haren adierazpenak erabat desberdinak izan behar.

Ikerketa diferentzialak, bere aldetik, baieztatzen du lagina osatzen duten taldeen iruditeriak aukeratutako hiru aldagaien arabera desberdinak direla. Desberdintasun esanguratsuak aurkezten dituzten itemak 18 dira, 
haietako bost bi aldagaietan $-29,11,25,09$ eta $12-$ eta item bat hiru aldagaietan $-06-$ errepikatzen direlarik.

Lehenengo aldagaiarekin - generoa - lotutako emaitzek hainbat desberdintasun azpimarragarri adierazten dituzte. Alde batetik, autonomiaren aldeko itemek aditzera ematen dute emakumeek, orokorrean, nolabaiteko zorroztasuna eta exijentzia autoritarioa aurkezten dutela (Hoffman, 1970; MacCoby eta Martin, 1983). Agerian uzten dute beren kideekiko mesfidantza profesionala, halabeharrezko egokitzapenarekiko kezka eskasa - gizonezkoena baino askoz altuagoa, azken horien kasuan agian ustekeria edo inpotentziagatik (Falk, 2018a) - eta, berriro ere, praktikotasunaren balioespena hausnarketaren aldean. Horiek guztiak bat datoz lehen aipatutako lanbidearen izaera feminizatuarekin, estilo millennialak inplikatzen duen nagusitasunarekin eta errealitate eta praktikaren arteko nahastearekin. Beste alde batetik, heteronomiaren aldeko hiru itemen balioespenak arau autoritarioarekin lotuta egongo lirateke. Hirurek generoen araberako desberdintasun antzekoa mantentzen dute, lehenengoa beste bien kontrako norabidean badoa ere. Horrela, emakumeak gelako kaosarekin - jolas goiztiarra jardueraren izaeragatik berezkoa eta saihestezina - gizonak baino permisiboagoak izango lirateke, baina askoz ere uzkurragoak - eta alde nabarmenez - gose eta asetasunaren kudeaketa autonomoarekin (Vincze, 2018) eta esfinterren kontrola baldintzatzearen aldekoak (Falk eta Vincze, 2018). Komenigarria litzateke ikertzea ea antzinako janari-maitasun (Hamburg et al., 2014) ideiarekin edo garbitasun goiztiarraren exijentziarekin lotutako kontu atabiko femeninoa den, familia-giroan normalean amak egindako jarduerak direlako ikasleria femeninoak gurasoen hezkuntza-estiloetatik ikasiko luke (Hoffman, 1970; MacCoby eta Martin, 1983).

Bigarren aldagaiari dagokionez - HH Gradurako sarbide-ikasketak-, emaitzek aditzera ematen dute bi laginetan intuiziozko iragazkiari lotutako (Goodman, 1988) haustura bat ematen dela, normatibitatea, eginbeharraren zentzua edo-eta nolabaiteko fatalismoa (Kellerhalls eta Montandon, 1997). Horrela, lanbide-heziketako ikasleria, batxilergotik datorrenarekin unibertsitate-formakuntza partekatu arren, erresistenteago izango litzateke hezkuntza goiztiarreko izatezko - eta horrexegatik ezinbestekoak - kontuak diren egokitzapenaren zailtasunei, harreraren kudeaketari eta jostailuen sozializazio autonomoari egoki erantzuten. Berriz, beren zeregina burutzeko eta alde praktikoa hausnarketaren kontra erreibindikatzeko joera aurkeztuko lukete, eta berarekin HHko Graduaren beraren formazio-helburua zalantzan jarriko. Joera hori millennial estiloaren autosufizientziarekin lotzeaz gain (Clark eta Byrnes, 2015) - alde batera uzten duten zerbait egiteko gai sentituko lirateke - errealitatea eta praktika nahastearen ondorio ere izan daiteke. Teoria eta praktika sinonimotzat hartzen dira sinesmen sinplistetan, baina aurrerakoienek badakite errealitatearen analisi eta gogoeta ona, elementu teoriko esanguratsuenak aintzat hartuz, praktika benetan eraldatzailea gida dezakeen gauza bakarra dela (Avgitidou et al., 2013; 
Vartuli eta Rohs, 2009). Bestalde, pixoihalaren aldaketaren balioespenetan bi taldeen arteko desberdintasunak - ez oso aldekoa lanbide-heziketan eta nahiko aurkakoa batxilergoan - aditzera ematen du gai hau lanbide-heziketaren eremu kurrikular bat dela, baina ez Graduarena. Item heteronomoek jakinarazten dute iragazkiaren eta informazio berriaren artean nolabaiteko koherentzia existitzen dela (Opfer eta Pedder, 2011; Opfer et al., 2011). Lanbide-heziketatik datorren ikasleriak batxilergokoak baino dezente argiago edukiko luke gatazka goiztiar gehienetan esku-hartze heldua ez litzatekeela beharrezkoa (Tardos eta Vasseur-Paumelle, 2018) eta hezkuntza goiztiarrean lotura-harreman ziur eta estuek pertsona heldu gutxirekin izan beharko luketela (Falk, 2013, 2018b).

Azkenik, bi zentro-moten arteko desberdintasunak ere ageri dira. Titulartasun publikoko ikasleak -1 . zentroa-, zehazki, laxoago, permisiboago eta ez hain esku-hartzaileak izango lirateke, erabakitzeko orduan, gehiago sinetsiko lukete haur-gaitasunean, haren potentzialitatean eta soziabilitatean edo beraien kabuz egiten utziko lukete, Hoffman-ek 1970ean proposatutako laissez faire-ren zentzuan. Horiek gehiago gozatuko lukete euren jardunaren aurrean eta sentiberatasun gutxiago adieraziko lukete ondoezaren aurrean. Beste era batera esanda, gehiago egiten utziko liekete beren kasa, eta haur-beharretara gutxiago egokituko lirateke. Aldiz, titulartasun pribatuko zentroko -2 . zentroa - ikasleek kontrola eta autoritaterako joera handiagoa izango lukete.

Laburbilduz, egungo ikasleriak zailtasun handiak edukiko lituzke hezkuntza goiztiarraren intuiziozko iragazkia, batez ere arauemaile eta autoritarioa, desegiteko eta beren eguneroko jardueran autonomia goiztiarra modu egokian sustatzearen garrantziari buruzko kontzientzia hartzeko, eta ondoren, praktikan egiten ikasteko. Horrek guztiak Haur Hezkuntzako Graduko formakuntzari erronka handi bat planteatzen dio. Alde batetik, bere eduki zehatzak ezartzea -ondorengo hezkuntza-mailakoei dagozkienak kenduz - , eta bestetik, intuiziozko iragazki desberdinek osatzen dituzten sinesteei heltzea, horiek desegitea eta ikasleriak benetan informatutako, egiazko eta eguneratutako informazioa jasotzea - beren siniste informatuak sortuz-. Zentzu horretan, eta beren erabaki-hartze prozesuetan aurreko sinesmenek noraino eragiten duten kontziente egin daitezen komenigarria izango litzateke Quite Time Observation (Loizou eta Recchia, 2018) bezalako esperientzia-estrategien bitartez esku hartzea edo ikasleriaren autokontzientzia lantzea (Di Santo, Timmons eta Lenis, 2017).

\section{ERREFERENTZIAK}

Akin, Z. (2013). Examining the beliefs of Turkish Preservice Early Childhood Teachers Regarding Early Childhood Curriculum. Journal of Research in Childhood Education, 27, 302-318. doi: 10.1080/02568543.2013.796331. 
Haurren autonomia goiztiarraren garapena eta Haur Hezkuntza Graduko...

Anliak S. eta Beyazkurk D. S. (2008) Career perspectives of male students in early childhood education. Educational Studies, 34(4), 309-317. doi: 10.1080/03055690802034518.

Avgitidou, S., Pnevmatikos, D. eta Likomitrou, S. (2013). Preservice teachers' beliefs about childhood: challenges for a participatory early childhood education? Journal of Early Childhood Teacher Education, 34(4), 390-404.

Baumirnd, D. (1991). Parenting styles and adolescent development. In R. M. Lerner, A. C. Petersen eta J. Brooks-Gunn (Arg.), Encyclopedia of adolescence, vol. 2 (746-758 orr.). New York: Garland Publishing.

Brownlee, J., Berthelsen, D., Irving, K., Boulton-Lewis, G. eta McCrindle, A. (2000). Caregivers' beliefs about Practice in Infant Child Care Programmes. International Journal of Early Years Education 8(2), 155-165. doi: 10.1080/09669760050046192.

Clark, S. eta Byrnes, D. (2015) What Millennial Preservice Teachers Want to Learn in Their Training. Journal of Early Childhood Teacher Education, 36(4), 379-395.

Clarke-Stewart, K. A., Vandell, D. L., Burchinal, M., O’Brien, M. eta McCartney, K. (2002). Do regulable features of child-care homes affect children's development? Early Childhood Research Quarterly, 17, 52-86. doi: 10.1016/ S0885-2006(02)00133-3.

David, M. eta Appell, G. (2010). Lóczy. Una insólita atención personal. Bartzelona: Octaedro.

Davis, B., eta Degotardi, S. (2015). Educators' Understandings of, and Support for, Infant Peer Relationships in Early Childhood Settings. Journal of Early Childhood Research, 13(1), 64-78. doi: 1476718X14538600.

Deci, E. L., eta Ryan, R. M. (1980). Self-determination theory: When mind mediates behavior. The Journal of Mind and Behavior, 1(1), 33-43.

Di Santo, A., Timmons, K. eta Lenis, A. (2017). Preservice early childhood educators' pedagogical beliefs. Journal of Early Childhood Teacher Education, 38(3), 223-241. doi: 10.1080/10901027.2017.1347588.

Duckworth, A. L. (2011). The significance of self-control. Proceedings of the $\mathrm{Na}$ tional Academy of Sciences, 108(7), 2639-2640.

Edwards, Allen L. (1953). The relationship between the judged desirability of a trait and the probability that the trait will be endorsed. Journal of Applied Psychology, 37(2), 90-93.

Erikson, E. H. (1963). Infancia y Sociedad. Buenos Aires: Ediciones Horme.

Falk, J. (2013). Si tocamos el cuerpo del bebé... In J. Falk (arg.) Bañando al bebé. El arte del cuidado (7-16 orr.). Budapest: Asociación Pikler-Lóczy de Hungría.

Falk, J. (2018a). Los fundamentos de la verdadera autonomía. In E. Herrán (arg.), Claves de la educación Pikler-Lóczy: Compilación de 20 artículos escritos por sus creadoras (89-114 orr.). Budapest: Asociación Pikler-Lóczy de Hungría.

Falk, J. (2018b). Claves de la continuidad en la educación de los niños que viven en una casa cuna. Adaptación, continuidad y salida de la institución. In E. Herrán (arg.). Claves de la educación Pikler-Lóczy: Compilación de 20 artículos escritos por sus creadoras (277-344 orr.). Budapest: Asociación Pikler-Lóczy de Hungría.

Falk, J. eta Vincze, M. (2018). El desarrollo del control de esfínteres y el interés del niño pequeño hacia las funciones corporales. In E. Herrán (arg.). Claves de 
la educación Pikler-Lóczy: Compilación de 20 artículos escritos por sus creadoras, (163-178 orr.). Budapest: Asociación Pikler-Lóczy de Hungría.

Field, F. (2010): The Foundation Years: Preventing Poor Children Becoming Poor Adults. The Report of the Independent Review on Poverty and Life Chances. London: Cabinet Office.

Gadeyne, E., Ghesquiere, P. eta Onghena, P. (2004). Longitudinal relations between parenting and child adjustment in young children. Journal of Clinical Child and Adolescent Psychology, 33(2), 347-358.

Gerhardt, S. (2014). Why love matters. How affection shapes a baby's brain. London: Routledge.

González-Mena, J. (2004). What can an orphanage teach us? Lessons from Budapest. Young children, 59(5), 26-29.

Goodman, J. (1988). Constructing a practical philosophy of teaching: A study of preservice teachers' professional perspectives. Teaching and Teacher Education, 4(2), 121-137.

Goodnow, J. J. (1985). Change and variation in ideas about childhood and parenting. In I. E. Sigel, (Ed.), Parental belief systems: The psychological consequences for children (235-270 orr.). Hillsdale: Erlbaum.

Hamburg, M.E., Finkenauer, C. eta Schuengel, C. (2014). Food for love: the role of food offering in empathic emotion regulation. Frontiers in Psychology, 5, 1-9. doi: 10.3389/fpsyg.2014.00032.

Herrán, E. (2014). Pikler-Lóczy eredua: zaintzea denean hezkuntzaren abiapuntua. Tantak, 26(2), 77-100.

Herrán, E., Orejudo, S., Martínez de Morentín, J. I. eta Ordeñana, B. (2014). Actitudes docentes y autonomía en Educación Infantil 0-2: Un estudio exploratorio en la Comunidad Autónoma del País Vasco (CAPV). Revista de Educación, 365, 150-176.

Hoffman, M. L. (1970). Conscience, personality and socialization techniques. $\mathrm{Hu}$ man Development, 13, 90-126.

Hrdy, S. (2009). Mothers and others. Cambridge: Harvard University Press. Joussemet, M., Landry, R., eta Koestner, R. (2008). A self-determination theory perspective on parenting. Canadian Psychology/Psychologie Canadienne, 49(3), 194-200. doi:10.1037/a0012754.

Joussemet, M., Landry, R. eta Koestner, R. (2008). A self-determination theory perspective on parenting. Canadian Psychology/Psychologie canadienne, 49(3), 194-200.

Kamii, K. (1982). La autonomía como objetivo de la educación: implicaciones de la teoría de Piaget. Infancia y Aprendizaje, 18, 3-32.

Kellerhalls, J. eta Montandon, C. (1997) Les styles éducatifs. In F. De Singly, (Zuz.), La famille l'état des savoirs (194-200 orr.). Paris: Éditions La Découverte.

Loizou, E. eta Recchia, S. (2018). In-Service Infant Teachers Re-Envision Their Practice Through a Professional Development Program. Early Education and Development, 29(1), 91-103. doi: 10.1080/10409289.2017.1343561.

Lortie, D. C. (2002). Schoolteacher: A sociological study. Chicago: University of Chicago Press.

MacCoby, E. E. eta Martin, J. A. (1983) Socialization in the context of the family: parent-child interaction. In E. M. Hetherington eta P. H. Mussen (Arg.), 
Haurren autonomia goiztiarraren garapena eta Haur Hezkuntza Graduko...

Handbook of child psychology: vol. 4. Socialization, personality and social development (1-101 orr.). New York: Wiley.

Masten, A. (2001). Ordinary magic: Resilience processes in development. American Psychologist, 56(3), 227-238.

Moffitt, T. E., Arseneault, L., Belsky, D., Dickson, N., Hancox, R. J., Harrington, H. L., Houts, R., Poulton, R., Roberts, B., Ross, S., Sears, M., Thomson, M. eta Caspi, A. (2011). A gradient of childhood self-control predicts health, wealth, and public safety. PNAS, 108, 2693-2698. doi: 10.1073/ pnas. 1010076108 .

Morales, P. (2000). Medición de actitudes en psicología y educación. Madrid: Universidad Pontificia de Comillas.

Moreau, E. eta Mageau, G. A. (2013). Conséquences et corrélats associés au soutien de l'autonomie dans divers domaines de vie. Psychologie Française, 58(3), 195-227. doi: 10.1016/j.psfr.2013.03.003.

Opfer, V. D. eta Pedder, D. (2011). Conceptualizing teacher professional learning. Review of Educational Research, 81(3), 376-407. doi: 10.3102/0034654311413609.

Opfer, V. D., Pedder, D. G. eta Lavicza, Z. (2011). The role of teachers' orientation to learning in professional development and change: a national study of teachers in England. Teaching and Teacher Education, 27(2), 443-53. doi: 10.1016/j.tate.2010.09.014.

Pikler, E. (2018). La competencia del bebé. In E. Herrán (ed.), Claves de la educación Pikler-Lóczy: Compilación de 20 artículos escritos por sus creadoras (59-72 orr.). Budapest: Asociación Pikler-Lóczy de Hungría.

Poulton, R., Moffitt, T. E. eta Silva, P. A. (2015). The Dunedin Multidisciplinary Health and Development Study: overview of the first 40 years, with an eye to the future. Social Psychiatry and Psychiatric Epidemiology, 50(5), 679-693. doi: $10.1007 / \mathrm{s} 00127-015-1048-8$.

Raths, J. (2001). Teachers' beliefs and teaching beliefs. Early Childhood Research eta Practice, 3(1).

Rollins, B. C. eta Thomas, D. L. (1979) Parental support, power and control techniques in the socialization of children. In E. R. Burr et al. (arg.), Contemporary theories about the family (317-364 orr.). New York: Free Press.

Schwartz, S. (2003). A Proposal for Measuring Value Orientations across Nations. In Questionnaire development report of the European Social Survey. 2015/03/12an kontsultatua: http://www .europeansocialsurvey.org/ docs/methodology/core_ess_questionnaire/ESS_core_questionnaire_human_ values.pdf

Solís, M. (2015). The dilemma of combining positive and negative items in scales. Psicothema, 27(2), 192-199.

Tardos, A. eta Vasseur-Paumelle A. (2018). Reglas y límites en la guardería, adquisición de actitudes. En E. Herrán (arg.). Claves de la educación PiklerLóczy: Compilación de 20 artículos escritos por sus creadoras (377-392 orr.). Budapest: Asociación Pikler-Lóczy de Hungría.

Tarullo, A., Obradovic, J. eta Gunnar, M. (2009). Self-control and the developing brain. Zero to tree, 29(3), 31-37.

Tomasello, M. (2007). Los orígenes culturales de la cognición humana. Buenos Aires: Amorrortu. 
Tonyan, H. A., Mamikonian-Zarpas, A. eta Chien, D. (2013). Do they practice what they preach? An Ecocultural, multidimensional, group-based examination of the relationship between beliefs and behaviours among child care providers. Early Child Development and Care, 183(12), 1853-1877. doi: 10.1080/03004430.2012.759949.

Vartuli, S. eta Rohs, J. (2009). Early childhood prospective teacher pedagogical belief shifts over time. Journal of Early Childhood Teacher Education, 30(4), 310-327.

Vincze, M. (2018). Del biberón a la autonomía. En E. Herrán (Arg.). Claves de la educación Pikler-Lóczy: Compilación de 20 artículos escritos por sus creadoras (207-229 orr.). Budapest: Asociación Pikler-Lóczy de Hungría.

Wallon, H. (1985). La vida mental. Barcelona: Crítica.

Weinstein, C. S. (1989). Teacher education students' preconceptions of teaching. Journal of Teacher Education, 40(2), 53-60. 